\title{
Clear Cell Hepatocellular Carcinoma
}

National Cancer Institute

\section{Source}

National Cancer Institute. Clear Cell Hepatocellular Carcinoma. NCI Thesaurus. Code C5754.

A morphologic variant of hepatocellular carcinoma characterized by the presence of clear cells. 